\title{
FLOODED NATIVE PASTURES OF THE NORTHERN REGION OF THE PANTANAL OF MATO GROSSO: BIOMASS AND PRIMARY PRODUCTIVITY VARIATIONS
}

\author{
POZER, C. G. and NOGUEIRA, F. \\ Programa de Pós-graduação em Ciências Biológicas, Instituto de Biociências, Universidade Federal de Mato \\ Grosso, Av. Fernando Correa da Costa, s/n, CEP 78060-900, Cuiabá, MT, Brazil \\ Correspondence to: Carla Graziela Pozer, Av. Nossa Senhora de Copacabana, n. 479, apt. 1101, CEP 22020-002, \\ Copacabana, Rio de Janeiro, RJ, Brazil, e-mail: cgpozer@ig.com.br \\ Received September 8, 2003 - Accepted November 25, 2003 - Distributed November 30, 2004
}

(With 3 figures)

\begin{abstract}
The Pantanal comprises a number of landscape units, submitted to a flood pulse with variable intensity or regularity. One of these units, the flooded plains, is important in cattle raising. This study was carried out in the northern portion of the Pantanal and presents data related to the productive dynamics of the flooded native pastures both protected from and exposed to cattle. The greatest total biomass values were for the protected pasture due to accumulated dead biomass. Net primary production presented smaller values at the flood-season start and increasing gradually beginning in the subsequent rainy season. However, consumption by cattle was also more intense during the months of greater precipitation. The effect of cattle in pastures is of fundamental importance to management since it prevents the dead biomass excess that increases fire risks.
\end{abstract}

Key words: native pastures, Pantanal, biomass, productivity.

\section{RESUMO}

\section{Pastagens nativas inundáveis da região norte do Pantanal de Mato Grosso: variações de biomassa e de produtividade primária}

O Pantanal abriga diversas unidades de paisagens, diferenciadas pela intensidade ou regularidade a que são submetidas ao pulso de inundação. Dentre essas unidades, os campos inundáveis se destacam no uso para a pecuária. O presente estudo foi realizado na parte norte do Pantanal e apresenta dados relativos à dinâmica produtiva de pastagens nativas inundáveis protegidas e não protegidas da ação do gado. Os maiores valores de biomassa total ocorreram na pastagem protegida, pois a ausência de consumo resulta em acúmulo de biomassa morta. A produtividade primária líquida apresentou menores valores no início da inundação, aumentando gradativamente a partir do novo período chuvoso. O consumo pelo gado também foi mais intenso nos meses de maior precipitação. A ação do gado sobre a pastagem é de fundamental importância para o manejo, uma vez que essa atividade evita o excesso de biomassa morta, o que aumentaria os riscos de incêndios.

Palavras-chave: pastagens nativas, Pantanal, biomassa, produtividade.

\section{INTRODUCTION}

The Pantanal of Mato Grosso is an extensive periodically flooded plain made up of a number of landscape units, subject to flood pulses with variable intensity and regularity. There are permanently flooded, sporadically flooded, and periodically flooded areas (Nogueira et al., 2002).

Within the periodically flooded units, fields present the greatest area and economic potential. Traditionally, these fields are used for extensive cattle raising (Silva et al., 2001; Seidl et al., 2001). However, 
limitations to this type of cattle raising are significant, not only because of periodic flooding, but also for lack of rain during a few months annually.

Various studies have described ecological processes in native pastures of the Pantanal (David, 2001; Nogueira et al., 2002; Ferraz, 2003; Rebellato, 2003). These studies indicate that during the dry period, organic matter accumulates on the soil surface. When the flood season begins, an accelerated decomposition process starts and, consequently, nutrient liberation occurs. These studies also indicate that plant material decomposition during the flood season transfers nutritionally rich organic debris to the pastures, maintaining them fertile during the dry period. Furthermore, the aquatic plant community becomes terrestrial throughout the flood pulse.

Other authors have provided information focused more narrowly on management. According to Comastri Filho (1984), pasture availability in the Pantanal is determined by the flood regimes and by pasture cover during the dry spell. Cattle raising has not caused significant impact on the Pantanal, but it certainly alters the productive dynamic of the flooded plain (Junk et al., 2000).

Deeper understanding of these processes is essential since cattle raising is one of the few economically viable alternatives for the Pantanal. Furthermore, in conservation areas, cattle have been removed and plant response is not yet known. The present work aims to contribute to clarifying the function of inundated pastures of the Pantanal, specially in plant production, as it is affected by seasonality (drought/flood) and direct cattle action.

\section{Study area}

The study was carried out in one of the flooded fields utilized as native pasture for a cattle herd in the northern Pantanal (Nossa Senhora Aparecida Farm, Municipality of Nossa Senhora do Livramento, State of Mato Grosso, Brazil, Fig. 1). Panicum laxum, Setaria geniculata, Reimarochloa brasiliensis, and Axonopus leptostachyus are the most common species, among other grasses and cyperaceae. The area was chosen due to greater access during the flooding phase and ease of field measurements. During the rainy period (November to March), in addition to precipitation, the area receives overflow from lakes and small rivers. As an example, the water column reached a $30 \mathrm{~cm}$ depth in 2001. The climate in the northern part of the Pantanal corresponds to Köpen AW, with a dry winter, humid summer, and precipitation varying between 1,000 and 1,400 mm/year (Allem \& Valls, 1987). During the more humid, hotter months after the floods, vegetation typical of the pasture is normally replaced by aquatic macrophytes, changing the local landscape.

\section{METHODS}

Annual variation estimate of plant production was carried out in three types of pasture areas: the first, permanently protected; the second, protected temporally; and the third, exposed. The permanently protected areas (PPA) showed biomass variation in the absence of cattle. The first sample was carried out after 60 days of protection in five $25 \mathrm{~m}^{2}$ wirefenced areas. The temporally protected areas (TPA) were represented by part of the vegetation protected by mobile $2.25 \mathrm{~m}^{2}$ screen structures, the locations of which were altered on the field every 30 days. The areas without protection (WPA) showed biomass variation in pastures exposed to cattle.

Biomass determination in each of the three cases was carried out monthly from December 2001 to November 2002. The destructive method, as proposed by Westlake (1969), was used as it has been in studies related to biomass determination (Howard-Williams, 1979; Nogueira \& Esteves, 1990; da Silva \& Esteves, 1993) and primary production (Mason \& Bryant, 1975; Sasser \& Gosselink, 1984; Machado, 1999). All plant material contained within $0.25 \mathrm{~m}^{2}$ quadrats was removed and separated in the laboratory into wet (photosynthetically active fraction) or dead (dried or decomposing plant debris) biomass.

Net primary productivity was considered as total primary production minus consumption by plant respiration, death and decomposition. It was estimated by:

$\mathrm{NPP}=\left(\right.$ TPA value month $2_{2}-$ TPA value $\left._{\text {month } 1}\right) / \mathrm{d}$ where:

$\mathrm{NPP}=$ net primary production;

TPA value month $2=$ biomass value estimated at the second month, on the temporally protected area;

TPA value ${ }_{\text {month } 1}=$ biomass value estimated at the first month, on the temporally protected area;

$\mathrm{d}=$ days between estimations .

The accumulated biomass was considered as that produced monthly and not respired or decomposed, and available to the cattle. It was estimated by: 


$$
\begin{gathered}
\mathrm{AB}=\left(\text { TPA value } \text { month } 1+\mathrm{TPA} \text { value }_{\text {month } 2}+\ldots\right. \\
\text { TPA value } \left._{\text {month 12 }}\right)
\end{gathered}
$$

where:

$\mathrm{AB}=$ accumulated biomass;

TPA value month $1_{1}=$ biomass value estimated at the first month on exposed areas;

TPA value mont $2_{2}=$ biomass value estimated at the second month on the temporally protected area;

TPA value ${ }_{\text {month 12 }}=$ biomass value estimated at the twelfth month on the temporally protected area.

Cattle consumption was estimated by the difference between net primary productivity of the temporally protected pasture and net primary productivity of the non-protected pasture. This estimate was carried out during the period in which cattle were in the pasture (December 2001; January, July, August, September, October, and November 2002).

Non-parametric tests of average comparison were used since the data distribution was not normal (Two-Sample Kolmogorov-Smirnov Test, $\mathrm{p} \leq$ 0.05 , SPSS 10.0). The aim was to detect significant differences between: 1) total biomass of protected and non-protected pasture; 2) wet and dead biomass of protected and non-protected areas; and 3) total biomass of the drier and wetter $(>60 \mathrm{~mm}$ in the month, or $>100 \mathrm{~mm}$ in the previous month, after Rizzini, 1997) months for protected and non-protected pastures.

\section{RESULTS}

There was a significant difference between average biomass (total, wet, and dead) in the different areas of pasture protection (Table 1). A significant difference between wet biomass values in protected pasture were detected when the most humid months (December, January, February, March, April, May, October, and November) were compared to the drier months (June, July, August, and September) and the same was found for dead biomass in the exposed pasture (Table 2). Wet biomass values decreased temporally under the two protected conditions, while the opposite tendency for dead biomass values was recorded (Fig. 2).

Net primary production was lower in the beginning of the flood, increasing gradually from July ( $8.0 \mathrm{~mm}$ rainfall) to the beginning of the next rainy period (Fig. 3). The greatest values for accumulated biomass increment $\left(3.8 \mathrm{gDW} \cdot \mathrm{m}^{-2}\right.$. day $\left.{ }^{-1}\right)$ were registered in May (end of flood) and November (5.1 $\mathrm{gDW} \cdot \mathrm{m}^{-2} \cdot$ day $\left.^{-1}\right)$. Wet biomass consumption by cattle was greater during the months of greater precipitation.

\section{DISCUSSION}

\section{Flood period}

The studied flooded plain remained dry for most of the year. According to the Brazilian Navy, before 2001 the Paraguay River suffered the greatest drought in the previous 28 years (Galdino, 2002). A brief flood occurring from March to April 2001 was due to accumulated rainwater, a phenomena known as the rain or pluvial pulse (Allem \& Valls, 1987; Pott, 1988; Santos, 1997).

\section{Cattle presence and biomass variation}

The higher averages of wet and dead biomass in the protected area are due to accumulated nonconsumed biomass (wet and dry organic matter). On the exposed pasture, trampling prevents dead biomass accumulation, not only by physically damaging decomposing plant material (Kinyamario \& Imbamba, 1992) but also by its impact on the wet pasture, which destroys part of nonconsumed plants (Melado, 2002). In the protected areas, absence of trampling and the different succession processes can also contribute to biomass accumulation, since some dead plants, when not removed, inhibit new sprouts. On the other hand, Rebellato (2003) observed greater plant species richness in the same area.

At the end of the year (October and November), wet biomass tended to decrease on both the protected and exposed pastures, while dead biomass presented an increase apparently related with precipitation and productivity increases. On the exposed pasture, decreasing wet biomass was linked to the greater degree of coverage of Reimarochloa brasiliensis, a creeping species with low biomass, beginning in the drier months. Other studies (Pucheta et al., 1998; Noy-Meir et al., 1989) on growth development of pastured and non-pastured areas, showed that species with short low-lying growth (e.g., Reimarochloa brasiliensis) are abundant in pastured areas. However, in areas of cattle exclusion, tall and erect species (e.g., Panicum laxum and Setaria geniculata) are more plentiful. The temporal accumulation of dead biomass was also observed by Heringer \& Jacques (2002) in native forage of Minas Gerais, where greater quantities of dead 
material on pastures free from fire and clearing, and smaller mineralization rate of plant remains were observed.

\section{Biomass and precipitation variation}

Total biomass values were not different between the most humid and the drier months in both protected and non- protected pastures, because terrestrial species can be replaced by aquatic species (Penha et al., 1998). Some terrestrial species were also observed to survive the short flood period. Even during an atypical flood year, some species characteristic of flooded soils continued growing in the pastures (e.g., Dioidia kuntzei). In addition, grass biomass can resist a few weeks of flood, even under strong stress, as long as parts of the leaves are above the water surface (Beard \& Martin, 1967, apud Haddade et al., 2002; Allem \& Valls, 1987).

Management adopted in the region implies cattle removal before the flooding period because of damage to animal hoofs by soaking in the soil, and also lack of food, when the water column is deep (Allem \& Valls, 1987). During the beginning as well as the end of the flooded period, this kind of strictly practical management effective protects pasture from damage caused by trampling, including soil and sprout compression (Pott, 1982; Melado, 2002).

\section{Productivity variation}

Native pastures of the Pantanal have intra-annual (seasonal) and inter-annual dynamics (drought/flood cycles) (Pott, 1982). Some species occupy new areas in or disappear from the topographic gradient, according to the water table level. Many species appear during the rainy season and disappear in the dry season. Depending on humidity, temperature, soil fertility, and management (Machado, 1999), plant growth will result in greater or lesser increments in the wet biomass.

In January 2001 there was a significant floodrelated decrease in net primary productivity.

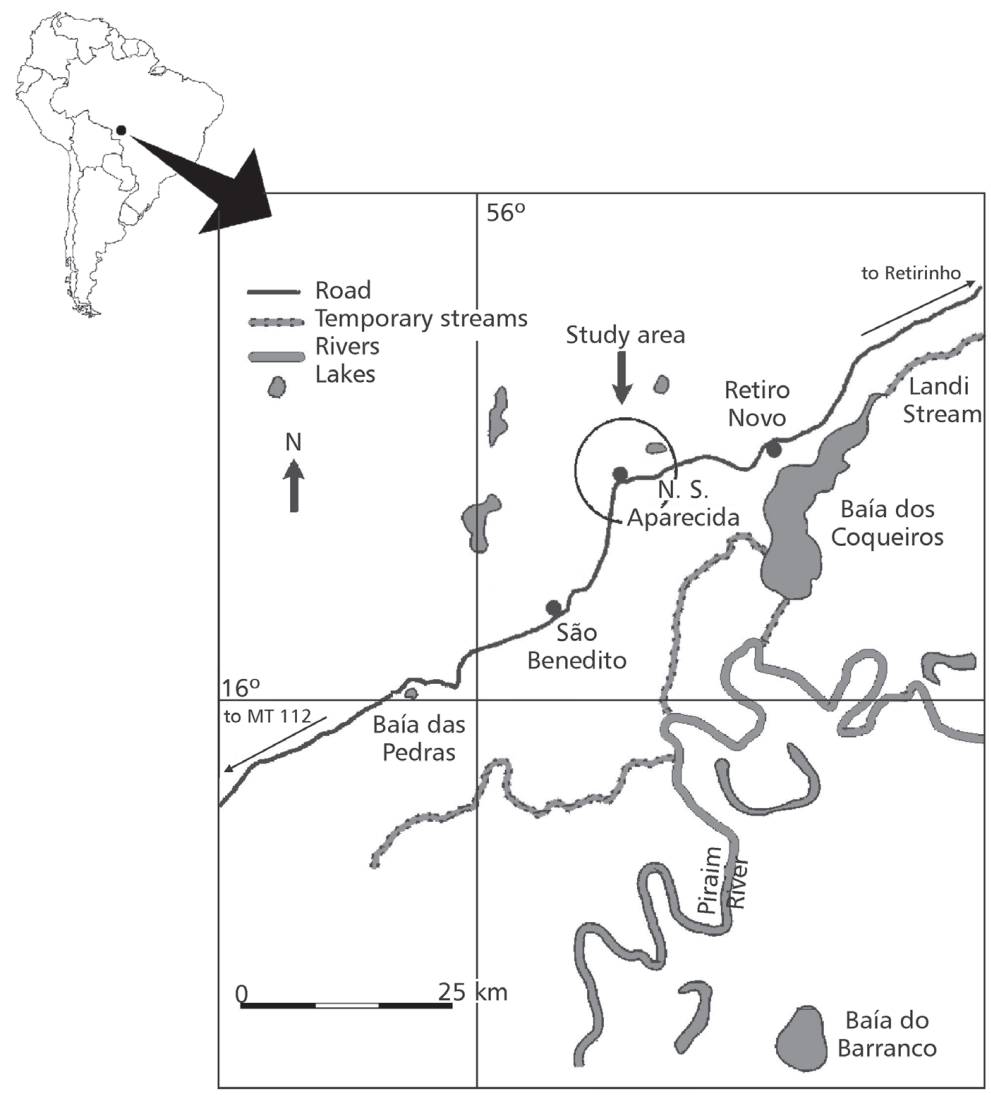

Fig. 1 - Study area: native pastures of northern Pantanal of Mato Grosso (Municipality of Nossa Senhora do Livramento, Mato Grosso, Brazil). 
TABLE 1

Total, dead, and wet biomass (gDW.m ${ }^{-2}$ ) under the different conditions.

\begin{tabular}{|c|c|c|}
\hline Biomass & $\begin{array}{l}\text { Protected } \\
\text { pasture }\end{array}$ & $\begin{array}{c}\text { Non-protected } \\
\text { pasture }\end{array}$ \\
\hline \multicolumn{3}{|l|}{ Total biomass } \\
\hline Mean & $551.10^{a}$ & $343.86^{b}$ \\
\hline S.D. & 173.03 & 159.11 \\
\hline Minimum & 173.16 & 44.04 \\
\hline Maximum & $1,192.16$ & 995.28 \\
\hline \multicolumn{3}{|l|}{ Wet biomass } \\
\hline Mean & $263.53^{\text {aA }}$ & $205.89^{\mathrm{bA}}$ \\
\hline S.D. & 115.55 & 104.12 \\
\hline Minimum & 20.24 & 42.88 \\
\hline Maximum & 567.16 & 464.84 \\
\hline \multicolumn{3}{|l|}{ Dead biomass } \\
\hline Mean & $281.64^{\mathrm{aA}}$ & $138.92^{b B}$ \\
\hline S.D. & 161.52 & 96.88 \\
\hline Minimum & 0.40 & 12.40 \\
\hline Maximum & 688.36 & 476.88 \\
\hline
\end{tabular}

Values followed by the same small and capital letter on the same line and in the same column do not differ significantly (Two-Sample Kolmogorov Smirnov Test, $\mathrm{p}<0.05$ ).

TABLE 2

Wet and dead total biomass $\left(\mathrm{gDW} \cdot \mathrm{m}^{-2}\right)$ in protected and non-protected pasture.

\begin{tabular}{|c|c|c|c|c|c|}
\hline \multirow{2}{*}{ Condition } & \multirow{2}{*}{$\begin{array}{c}\text { Rain } \\
\text { regime }\end{array}$} & \multirow{2}{*}{ Statistics } & \multicolumn{3}{|c|}{ Biomass $\left(\mathrm{gDW} \cdot \mathrm{m}^{-2}\right)^{*}$} \\
\hline & & & Total & Wet & Dead \\
\hline \multirow{8}{*}{$\begin{array}{c}\text { Protected } \\
\text { pasture }\end{array}$} & \multirow{4}{*}{$\begin{array}{l}\text { Humid } \\
\text { months }\end{array}$} & Mean & $557.05^{A}$ & $298.58^{A}$ & $253.36^{A}$ \\
\hline & & S.D. & 116.52 & 66.07 & 129.66 \\
\hline & & maximum & 725.59 & 431.19 & 392.06 \\
\hline & & minimum & 357.91 & 212.79 & 66.03 \\
\hline & \multirow{4}{*}{$\begin{array}{c}\text { Dry } \\
\text { months }\end{array}$} & Mean & $539.16^{\mathrm{A}}$ & $193.44^{B}$ & $338.19^{A}$ \\
\hline & & S.D. & 78.15 & 68.20 & 37.47 \\
\hline & & maximum & 608.9 & 288.52 & 390.22 \\
\hline & & minimum & 457.11 & 133.99 & 300.81 \\
\hline \multirow{8}{*}{$\begin{array}{c}\text { Non- } \\
\text { protected } \\
\text { pasture }\end{array}$} & \multirow{4}{*}{$\begin{array}{l}\text { Humid } \\
\text { months }\end{array}$} & Mean & $320.69^{A}$ & $209.96^{A}$ & $112.17^{\mathrm{A}}$ \\
\hline & & S.D. & 55.48 & 64.81 & 63.38 \\
\hline & & maximum & 401.86 & 284.86 & 244.13 \\
\hline & & minimum & 242.42 & 109.52 & 50.94 \\
\hline & \multirow{4}{*}{$\begin{array}{c}\text { Dry } \\
\text { months }\end{array}$} & Mean & $390.18^{A}$ & $197.75^{\mathrm{A}}$ & $192.43^{B}$ \\
\hline & & S.D. & 96.41 & 96.20 & 29.63 \\
\hline & & maximum & 476.34 & 314.44 & 229.66 \\
\hline & & minimum & 284.13 & 107.17 & 161.9 \\
\hline
\end{tabular}

*Values followed by the same letter in the column do not differ from each other for the same condition of protection (Two-Sample Kolmogorov-Smirnov Test, $\mathrm{p}<0.05$ ). 

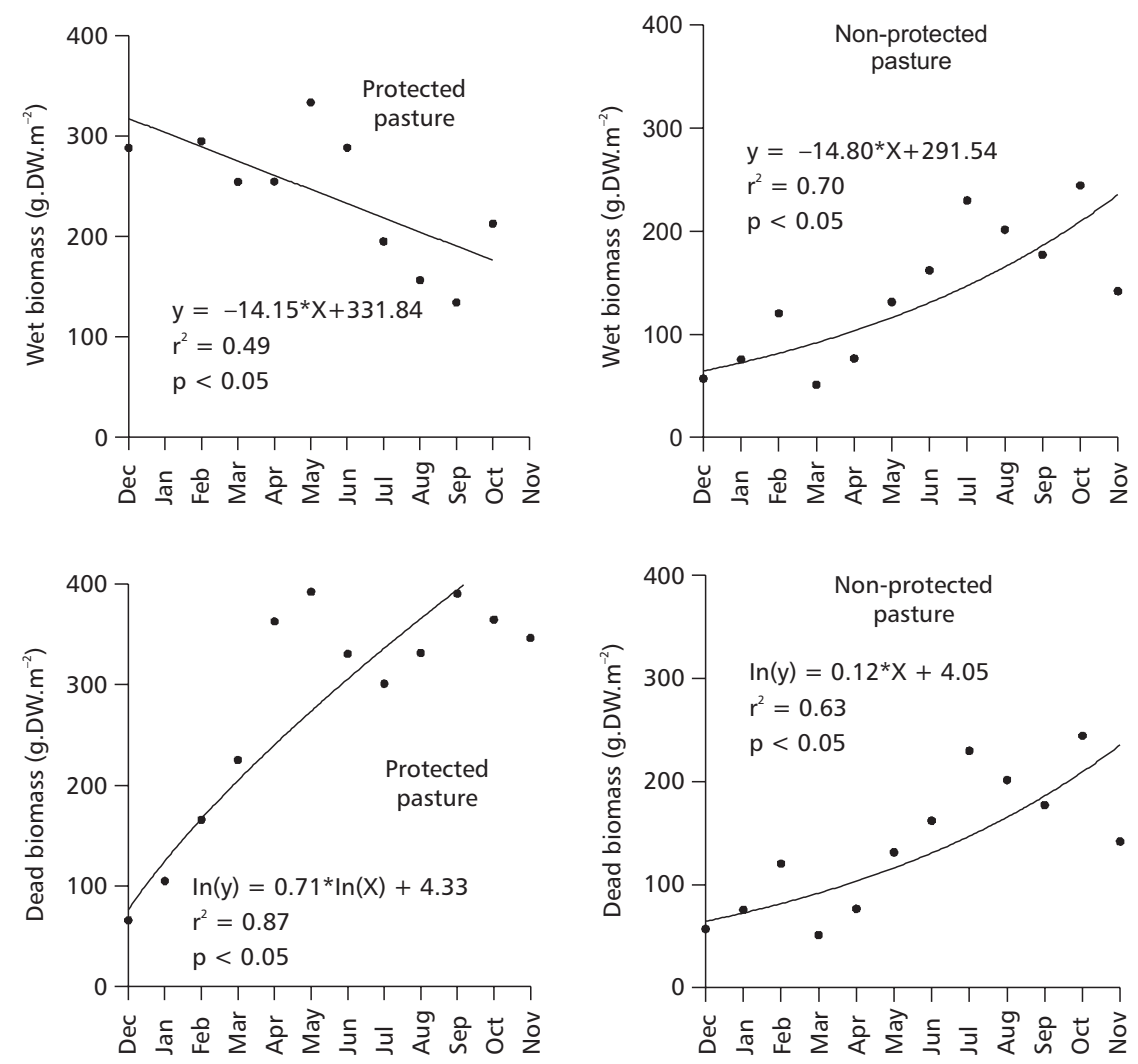

Fig. 2 - Annual (December 2000 to November 2001) wet and dead biomass variation (gDW.m-2) in protected and non-protected conditions in the Nossa Senhora Aparecida Farm on the flood plain, Pantanal of Mato Grosso, Brazil.

Because of an atypical flood, no growth of large aquatic macrophytes was detected and low primary production values were also registered during the flood period. For cultivated grass in the Pantanal of Mato Grosso do Sul (sub-region of Nhecolândia), lower productivity values (2.1 $\mathrm{gDW} \cdot \mathrm{m}^{-2}$.day $\left.{ }^{-1}\right)$ were also found during the flood (April) (Crispim et al., 1998).

In "normal" flood years (Collischonn et al., 2001; Galdino, 2002), productivity is greater in the Northern Pantanal. According to Penha et al. (1999), about 70\% of annual production occurs during the flood period, because species of larger aquatic macrophytes (e.g., Pontederia lanceolata) find better growing conditions.

By the end of the flood period the studied pasture remained humid, and productivity had increased, and cattle had not yet returned to the field. Higher productivity was due to nutrient recycling, following decomposition during the flood period (Junk \& Piedade, 1997; David, 2001). Productivity was smaller in July (a dry month) but since this was an atypical year, productivity increased again when brief rain occurred.

The greatest wet biomass increment was registered in the rainy months without flooding, when plant productivity not limited by nutrient conditions is greatest in the humid soil (Milchunas et al., 1994; Junk \& Furch, 1997). Greatest consumption of wet biomass by the cattle occurred when the highest primary production values were found; animal weight gains were recorded when pastures began sprouting.

In conclusion, the production dynamic of the native pasture studied was strongly influenced by the rain regime and cattle movement, even in a year of atypical flooding. Primary production increased after flood beginning, but consumption was more intense during the rainy months. Cattle presence in a pasture is of essential importance in Pantanal management, since this diminishes fire risks by preventing excess dead biomass. Conservation areas protected from cattle are more vulnerable to fires, especially in periods of extreme drought. 
A

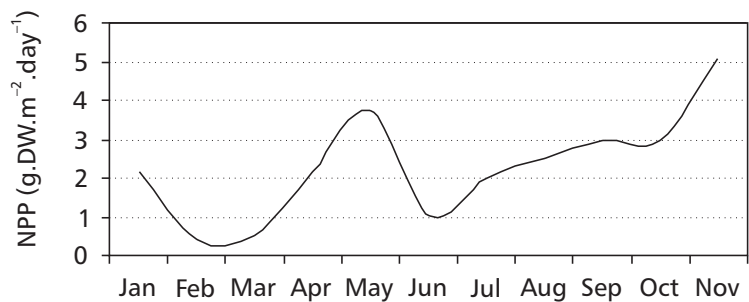

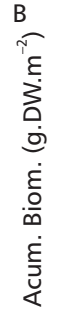

Jan Feb Mar Apr May Jun Jul Aug Sep Oct Nov

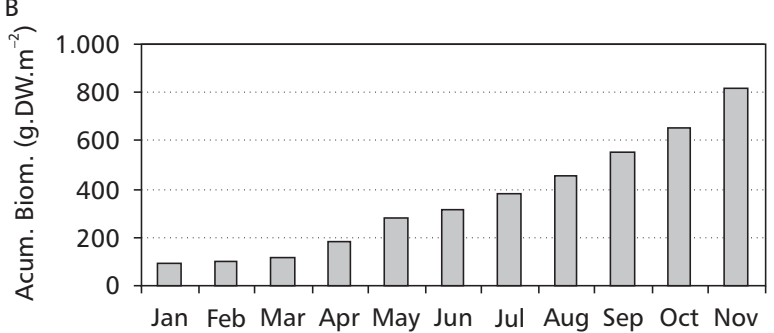

$\mathrm{C}$

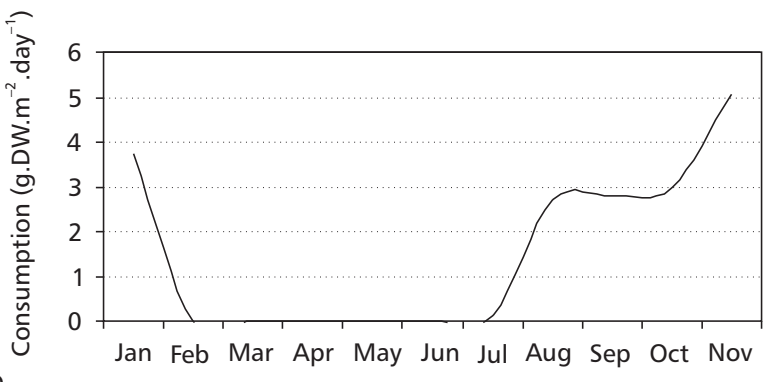

D

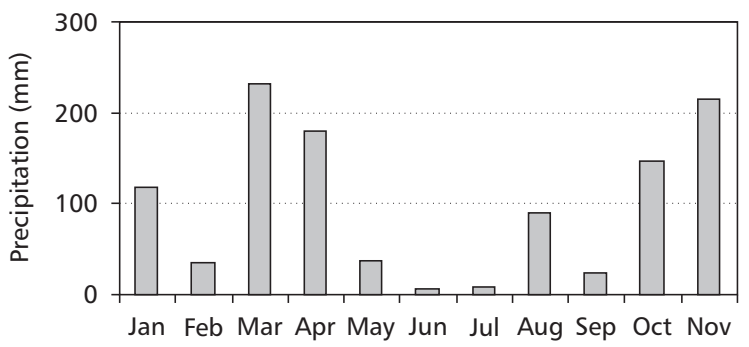

Fig. 3 - Annual variation of net primary productivity (NPP) $\left(\mathrm{gDW} \cdot \mathrm{m}^{-2} \cdot \mathrm{day}^{-1}, \mathrm{~A}\right)$, accumulated biomass $\left(\mathrm{gDW} \cdot \mathrm{m}^{-2}\right.$, B), consumption of pasture by cattle $\left(\mathrm{gDW} \cdot \mathrm{m}^{-2} \cdot \mathrm{day}^{-1}, \mathrm{C}\right)$, and monthly precipitation (D).

Acknowledgements - We are grateful to the SHIFT Program (CNPq/IBAMA/DLR)(Pantanal Ecology Project-IB UFMT/MPIL Plön) and FAPEMAT (Fundação de Amparo à Pesquisa do Estado de Mato Grosso) for financial support, and also to CAPES for a scholarship.

\section{REFERENCES}

ALLEM, A. C. \& VALLS, J. F. M., 1987, Recursos forrageiros nativos do Pantanal mato-grossense. EMBRAPA, Brasília, DF, 339p.

COLLISCHONN, W., TUCCI, C. E. M. \& CLARKE, R. T., 2001, Further evidence of changes in the hydrological regime of the River Paraguay: part of a wider phenomenon of climate change? Journal of Hydrology, 245: 218-238.
COMASTRI FILHO, J. A., 1984, Pastagens nativas e cultivadas no Pantanal Mato-grossense. Corumbá, EMBRAPA/UEPAE de Corumbá, 48p. (Circular Técnica, 13).

CRISPIM, S. M. A., FERNANDES, F. A., FERNANDES, A. H. B. M. \& CARDOSO, E. L., 1998, Produtividade de braquiárias na sub-região da Nhecolândia, Pantanal, MS, Brasil. EMBRAPA-CPAP, Corumbá, MS. (Pesquisa em andamento).

DA SILVA, C. J. \& ESTEVES, F., 1993, Biomass of three macrophytes in the Pantanal of Mato Grosso, Brazil. Inter. Journal of Ecology and Environmental Sciences, 19: 11-23.

DAVID, G. Q., 2001, Dinâmica de nutrientes em um campo inundável no Pantanal Mato-Grossense, Brasil. Dissertação de Mestrado, IB/UFMT, Cuiabá, MT, 79p. 
FERRAZ, L., 2003, Dinâmica de nutrientes em um campo alagável: velocidade de liberação causada pela inundação. Dissertação de Mestrado, IB/UFMT, Cuiabá, MT, 33p.

GALDINO, S., 2002, Pantanal registra o mais longo e intenso ciclo de cheia. Circular Técnica, EMBRAPA - CPAP, Corumbá, MS, $6 \mathrm{p}$.

HADDADE, I. R., OBEID, J. A., FONSECA, D. M., PEREIRA, O. G. \& PEDRON E SILVA, M. A., 2002, Crescimento de espécies forrageiras tropicais submetidas a diferentes períodos de alagamento. Rev. Bras. Zoot., 31(5): 1924-1930.

HERINGER, I. \& JACQUES, A. V. A., 2002, Acumulação de forragem e material morto em pastagem nativa sob distintas alternativas de manejo em relação às queimadas. Rev. Bras. de Zoot., 31(2): 599-604.

HOWARD-WILLIAMS, C., 1979, Distribution, biomass and role of aquatic macrophytes in Lake Sibaya, pp. 88-107. In: B. R. Allanson (ed.), Lake Sibaya. (Monographiae Biologicae, 36.)

JUNK, W. J., DA SILVA, C. J., WANTZEN, K. M., NUNES DA CUNHA, C. \& NOGUEIRA, F., 2000 (in press), The Pantanal of Mato Grosso: Status of ecological research, actual use, and possibilites for sustainable development. In: The Wetlands Handbook. Blackwell Science, London.

JUNK, W. J. \& FURCH, K., 1997, Physicochemical conditions in floodplains, pp. 69-107. In: W. J. Junk et al. (ed.), The central Amazon floodplain ecology of a pulsing System.

JUNK, W. J. \& PIEDADE, M. T. F., 1997, Plant life in the floodplain with special reference to herbaceous plants, pp. 147-185. In: W. J. Junk et al. (ed.), The central Amazon floodplain ecology of a pulsing system.

KINYAMARIO, J. I. \& IMBAMBA, S. K., 1992, Savanna at Nairobi National Park, Nairobi. In: S. P. Long, M. B. Jones \& M. J. Roberts (eds.), Primary productivity of grass ecosystems of the tropics and sub-tropics. Ed. Chapman \& Hall, London, New York.

MACHADO, L. A. Z., 1999, Manejo de pastagem nativa. Ed. Agropecuária LTDA, Guaíba, RS, 158p.

MASON, C. F. \& BRYANT, R. J., 1975, Production nutrient content and decomposition of Phragmites communis Trin. and Typha angustifolia L. Journal of Ecology, 63: 71-95.

MELADO, J., 2002, Manejo sustentável de pastagem. In: Coordenação Italiana (eds.), A Amazônia encontrando soluções. Embaixada da Itália, Brasília, 270p.

MILCHUNAS, D. G., FORWOOD, J. R. \& LAUENROTH, W. K., 1994, Productivity of long-term grazing treatments in response to seasonal precipitation. J. Range Manage, 47: 133-139.

NOGUEIRA, F., COUTO, E. G. \& BERNARDI, C. J., 2002, Geostatistics as a tool to improve sampling and statistical analysis in wetlands: a case study on dynamics of organic matter distribution in the Pantanal of Mato Grosso, Brazil. Braz. J. Biol., 62(4B): 861-870.
NOGUEIRA, F., ESTEVES, F. A. \& PRAST, A. E., 1996, Nitrogen and phosphorus concentration of different structures of the aquatic macrophytes Eichhornia azurea Kunth and Scirpus cubensis Poepp \& Kunth in relation to water level variation in Lagoa do Infernão (São Paulo, Brazil). Hydrobiologia, 328: 199-205.

NOY-MEIR, I., GUTMAN, M. \& KAPLAN, Y., 1989, Responses of Mediterranean grassland plants to grazing and protection. Journal of Ecology, 77: 290-310.

PENHA, J. M. F., DA SILVA, C. J. \& BIANCHINI JÚNIOR, I., 1998, Análise do crescimento da macrófita aquática Pontederia lanceolata em área alágavel do Pantanal Matogrossense, Brasil. Braz. J. Biol., 58(2): 287-300.

PENHA, J. M. F., DA SILVA, C. J. \& BIANCHINI JÚNIOR, I., 1999, Productivity of the aquatic macrophyte Pontederia lanceolata Nutt. (Pontederiaceae) on floodplains of the Pantanal Mato-grossense, Brazil. Wetlands Ecology and Management, 7: 155-163.

POTT, A., 1982, Pastagens das sub-regiões Paiaguas e Nhecolândia, do Pantanal Mato-grossense. EMBRAPA, UEPAE de Corumbá, Corumbá, 48p. (Circular técnica, 10).

POTT, A., 1988, Pastagens no Pantanal. EMBRAPA, PantanalCPAP, Corumbá, 58p. (Documentos, 7).

PUCHETA, E., CABIDO, M. \& FUNES, G., 1998, Floristic composition, biomass, and aboveground net plant production in grazed and protected sites in a mountain grassland of central Argentina. Acta Oecologica, 19(2): 97-105.

REBELLATO, L., 2003, Impacto do pastejo sobre a composição e estrutura da vegetação de um campo inundável no Pantanal de Poconé, MT. Dissertação de Mestrado, IB/UFMT, Cuiabá, MT, 55p.

RIZZINI, C. T., 1997, Tratado de fitogeografia do Brasil. Âmbito Cultural Edições Ltda., São Paulo, 2. ed., 747p.

SANTOS, S. A., 1997, Recomendações sobre manejo nutricional para eqüinos criados em pastagens nativas no Pantanal. EMBRAPA, CPAP, Corumbá, 63p.

SASSER, C. E. \& GOSSELINK, J. G., 1984, Vegetation and primary production in a floating freshwater marsh in Louisiana. Aquatic Botany, 20: 245-255.

SEIDL, A. F., SILVA, J. S. V. \& MORAES, A. S., 2001, Cattle ranching and deforestation in the Brazilian Pantanal. Ecological Economics, 36: 413-425.

SILVA, J. dos S. V. da, MORAES, A. S. \& SEIDL, A. F., 2001, Evolução da agropecuária no Pantanal brasileiro, 1975 1985. EMBRAPA-Pantanal, Corumbá, 157p.

SPSS 10.0, 1999, SPSS Base10.0 User's Guide. SPSS Inc., Chicago, 537p.

WESTLAKE, D. F., 1969, Sampling techniques and methods for estimating quantity and quality of macrophytes biomass, pp. 25-32. In: R. A. Vollenweider (ed.), A manual on methods for measuring primary production in aquatic environments. Oxford, Blackwell. (IBP Handbook 12). 